\title{
基質小胞プロテアーゼについて
}

長崎大学医学部整形外科

山田健治・松本智子

岩 㥓 幐 郎

長崎大学苳学部口沿生化学

桂啺 彦

The Protease Associated with Matrix Vesicles

by

Kenji Yamada, Tomoko Matsumoto, Katsuro Iwasaki

Department of Orthopaedic Surgery Nagasaki

University School of Medicine

Nobuhiko Katsura

Department of Oral Biochemistry Nagasaki

University School of Dentistry

The activity of matrix vesicle specific protease is completely inhibited by o-phenanthroline and restored by $\mathrm{Co}$ or $\mathrm{Zn}$ ions. Purified matrix vesicle protease shows no reaction with anti-collagenase (CLSII) serum.

はじめに

基質小胞（matrix vesicles）は, 1967 年, Anderson, Bonnuci らによって，石灰化前線に見い出 されて以来, 石灰化の initiater site と考えられて おり，坂田》 は基質小胞プロテアーゼが石灰化基質の 有機質胞部に関与しているととを示した. 藤原 ${ }^{3}$ は 基 質小胞プロテアーゼを精製し，ての性質を調べて，金 属プロテアーゼであるととを示した.とれらの研究で は，金属イオンの種類，調製時に使用したコラゲナー ゼに混在するプロテアーゼの混入の恐れはないととの 確認が未解決である. 本研究はてれらの点を明らかに するととを目的とした.

$$
\text { 方法 }
$$

\section{1. 基質小胞の分離, 精製}

仔牛又は 8 週令のニワトリの 骨端軟骨から, Vaananen, Korhonen ${ }^{8)}$ ら及び藤原 ${ }^{3}$ の方法により基質 小胞を分離した. すなわち，Fig. 1 亿示すごとく，骨 端軟骨をコラゲナーゼ (Worthington collagenrse

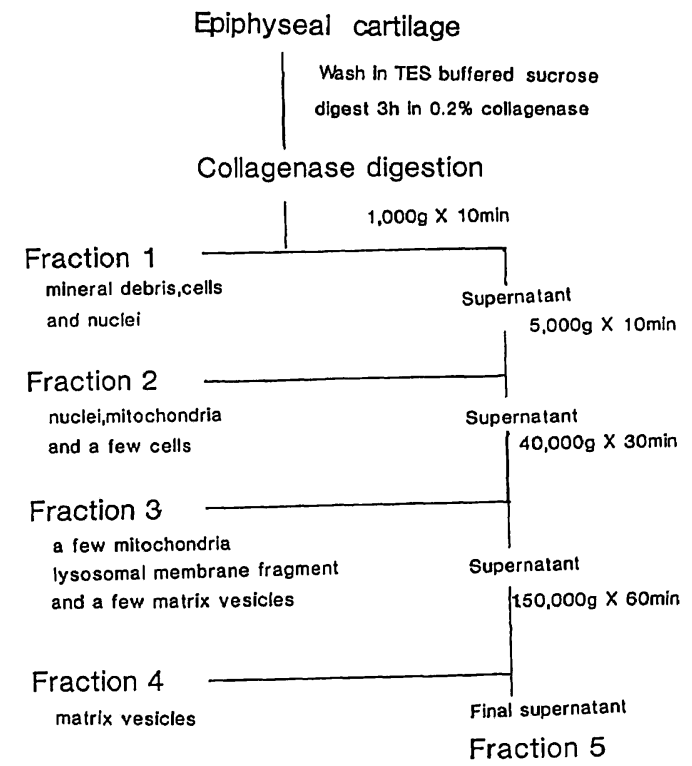

Fig. 1 Isolation schema ${ }^{8)}$ 


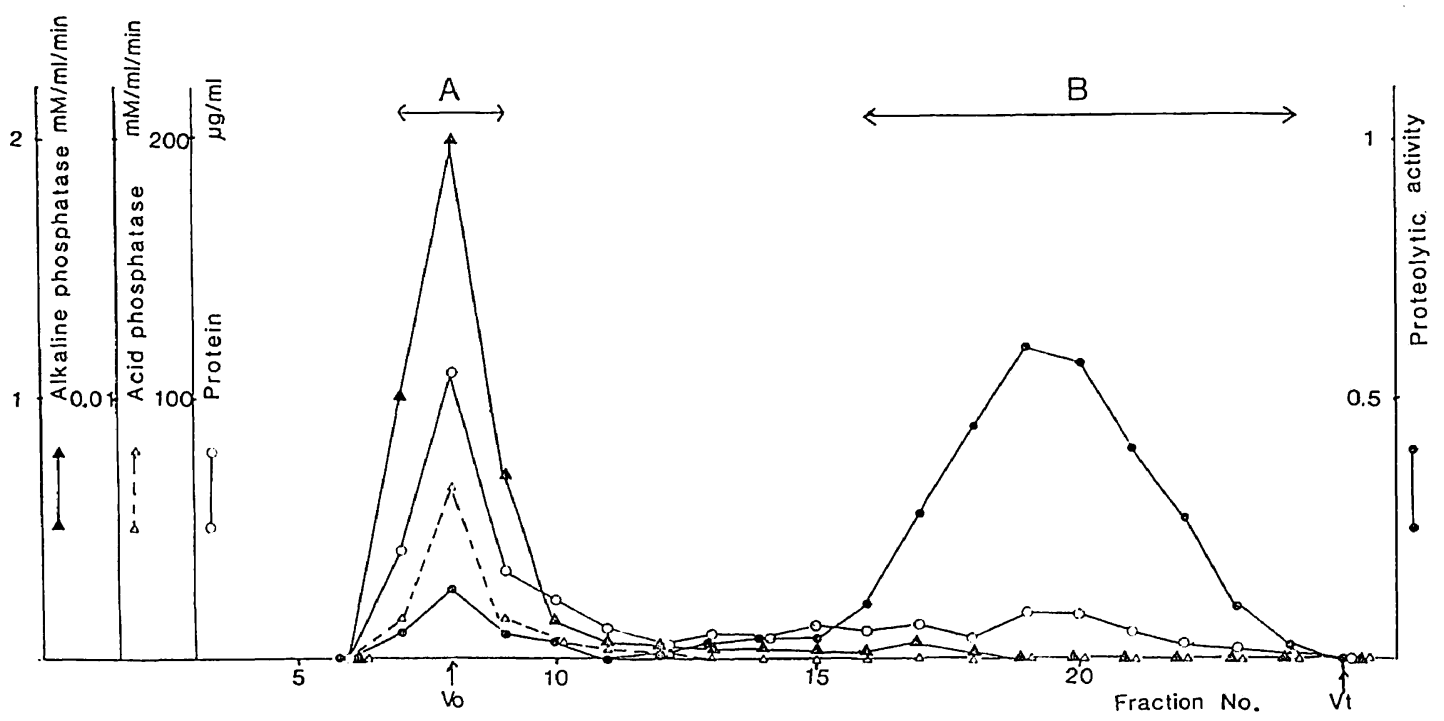

Fig. 2 Gel filtration of matrix vesicles of Sepharose CL2B

CLS II) $0.2 \%$ \%を含む, $50 \mathrm{mM}$ TES (N-tris (hydroxymethyl)-2-aminoethane sulfonic acid) buffer, $0.25 \mathrm{M}$ sucrose, $0.1 \mathrm{mM} \mathrm{CaCl}_{2} \mathrm{PH} 7.4$ で, 3 時間消化した後，遠心分離によって基質小胞分画 F 4 を得た。

次にF 4 をPercoll 密度勾配遠心を行う代りに Sepharose CL2B $(10 \times 450 \mathrm{~mm})$, elution buffer $0.2 \mathrm{M}$ Tris- $\mathrm{HCl} \mathrm{PH} 7.0$ にてゲルろ過を行い Vo に 溶出した分画（Fig. 2-A）を精製基質小胞分画とし た.

2. 基澌小胞プロテアーゼの分離

Sepharose CL2B 精製基質小胞分画を， $0.008 \%$, sodium deoxycholate で $12 \mathrm{~h}$ 処理後, 凍結乾燥 し，とれを Sephadex G $150(9 \times 450 \mathrm{~mm})$, elution buffer $0.2 \mathrm{M}$ Tris-HCl pH 7.0でゲルろ過を行い 基質小胞プロテアーゼを分離した。

3. 蛋白, 醣深活性の测定

需白は, Lowry 法によって测定した. アルカリ性 ホスファターゼ及び酸性ホスファターゼはそれぞれ， $0.05 \mathrm{M}$ carbonate buffer pH 10.5 , 及び $0.1 \mathrm{M}$ citrate buffer pH 5.0 で p-nitrophenyl phosphate を基睤として测定し，プロテアーゼ溶液勧位体 程当りの relative specific activity で示した. プロ テアーゼ活性は， $2 \%$ azo casein を基質として， Tris $-\mathrm{HCl} \mathrm{pH} 7.0$ で $12 \mathrm{~h}$ incubation し, 終濃度 5
\%に TCA を加えた後, $3,000 \mathrm{rpm} 10$ 分遠心し, 上 清を $0.5 \mathrm{M} \mathrm{NaOH}$ 中にて $450 \mathrm{~nm}$ の吸光度で示し た.

4. 抗コラゲナーゼ血清の作製

成熟家鬼にコラゲナーゼ (Worthington collagenase CLS II) と Freund's complete adjuvant を 皮内に投与し， 1 週後に Freund's incomplete ad. juvant とコラゲナーゼを投与, 更に 1 週後同様に投 与し，その 1 週後にコラゲナーゼのみを与えて， 1 週 後に採血，遠心して抗血清を得た。

5. 抗原抗体反応

抗原抗体反応は，二重免疫拡散法によって抗 CLS II 血清, 基質小胞, 基質小胞プロテアーゼとの間に行 った. すなわち, $1 \%$, agarose ゲル中にて, $48 \mathrm{~h}$ 反応後, $10 \%$ \%ミドブラック $10 \mathrm{~B}$ にて染色し, 沈 降線を観察した.

6. 金属イオンによるプロテアーゼ活性の回復 プロテアーゼが必要とする金属イオンの種類を調べ た. $0.5 \mathrm{mM}$ o-phenanthroline にて, プロテアーゼ 活性が完全に失活することを碓認した後， $0.5 \mathrm{mM}$ o-phenanthroline で 10 分間, preincubation して 失活させたプロテアーゼに各種の金属イオンを $1 \mathrm{mM}$ 加えて，プロテアーゼ活性の回復をみた. 金属はすべ て塩化物を使用した. 


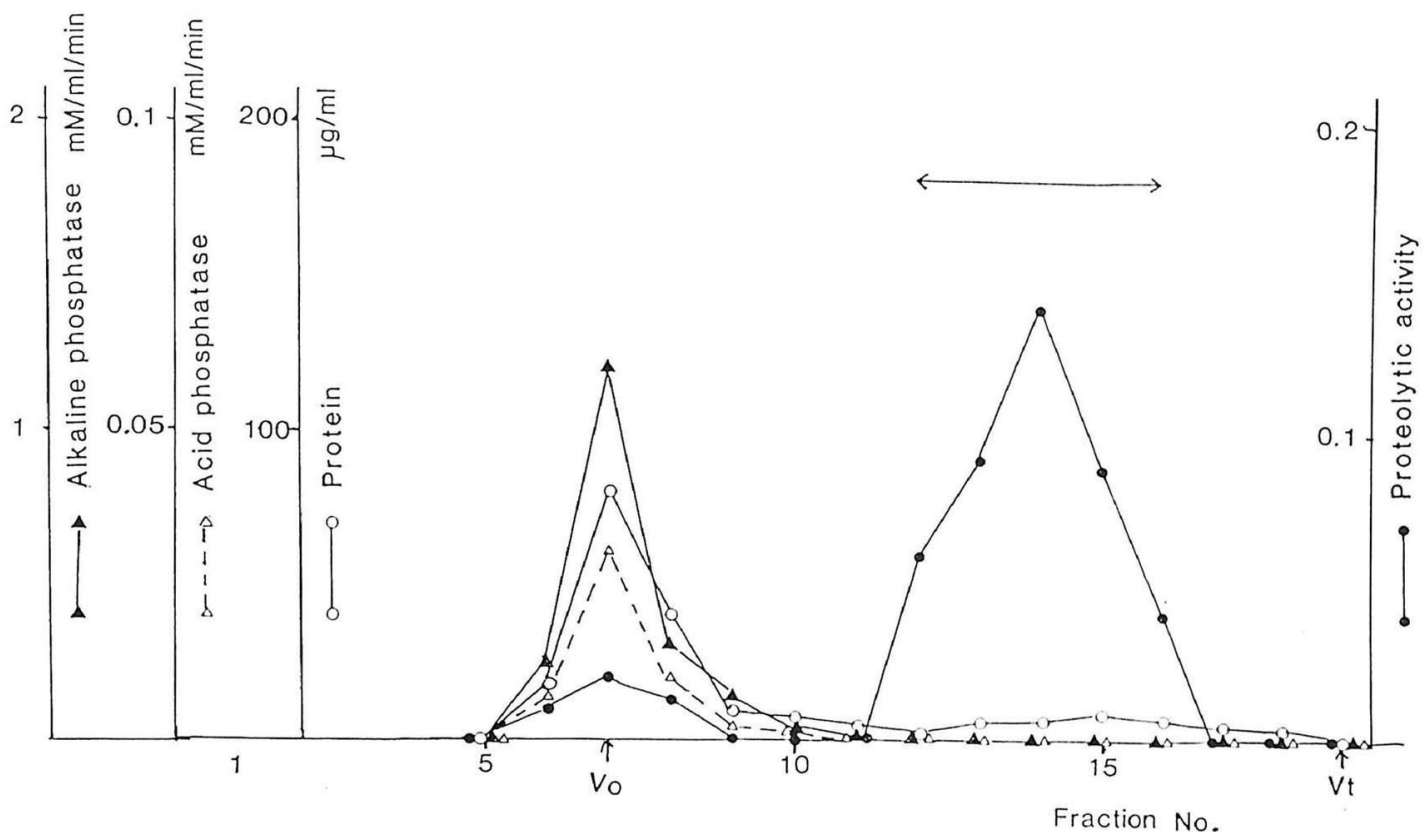

Fig. 3 Gel filtration of deoxycholate extracted and freeze dried protease on Sephadex G 150

結

F 4 を Sepharose CL2B でゲルろ過すると, Fig. 2 に示すごとく，プロテアーゼ活性は，A，B の 2 相 性を示す. Ali1 占示すたように基質小胞にはアルカ リ性ホスファーターゼが多く含まれており，Vor溶 出さ机たアルカリ性ホスファーターゼの多い A 分画 が，基質小胞分画である．B の分画のプロテアーゼ活 性はコラゲナーゼ由来のむのである. てれは，抗コラ ゲナーゼ血清の反応で碓認した.

炏にA の分画を $0.008 \%$ deoxycholate で処理 し，凍結乾燥したものを Sephadex G 150 でゲルろ 過すると Fig. 3 に示すでとく, プロテアーゼ活性の $88 \%$ が Kav $=0.6$ 付近に溶出された. $0.008 \%$ deoxycholate のみの処理では, $26 \%$ しか溶出されなか った. 又, $0.3 \%$ deoxycholate でむ $60 \%$ が溶出 される.

抗コラゲナーゼ血清との反応は, Fig. 4 亿示すで之 く, コラゲナーゼとのみ沈降線を認め，精製基質小 胞, Sephadex G 150 処理の基質小胞プロテアーゼと の間には沈降線を認めていない，上記の方法によって 精製した基質小胞プロテアーゼには，使用したコラゲ

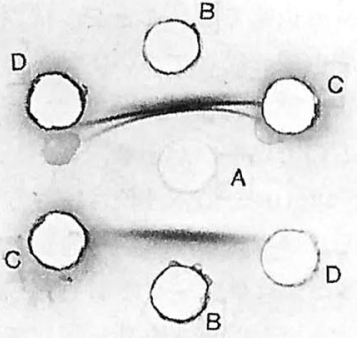
A: anti CLSII serum
B: collagenase(CLSII)
C: matrix vesicle
D: matrix vesicle protease

Fig. 4 Immunodiffusion reactivity

ナーゼに含まれるプロテアーゼは混入していないとと を確認した。

キレート剂によって失活させた基質小胞プロテアー ゼの金属イオンによる活性回復は, Table 1 に示すよ うに，コントロールのプロテアーゼ活性を $100 \%$ \%と て示した. プロテアーゼ活性は, $0.5 \mathrm{mM}$ の $\mathrm{EDTA}$, 
Table 1 Effect of metal ions

\begin{tabular}{l|c|c}
\hline $\begin{array}{c}\text { Substance } \\
\text { added }\end{array}$ & $\begin{array}{c}\text { Final conce- } \\
\text { ntration } \\
(\mathrm{mM})\end{array}$ & $\begin{array}{c}\text { Relative } \\
\text { activity } \\
(\%)\end{array}$ \\
\hline None & - & 100 \\
O-phena- & 0.5 & 0 \\
nthrotine & 0.5 & 0 \\
\hline EDTA & 0.5 & \\
\hline o-phena- & & \\
nthroline & 1.0 & 64 \\
and & 1.0 & 52 \\
CoCl & 1.0 & 0 \\
$\mathrm{ZnCl}_{2}$ & 1.0 & 0 \\
$\mathrm{CaCl}_{2}$ & 1.0 & 0 \\
$\mathrm{MgCl}_{2}$ & 1.0 & 31 \\
$\mathrm{LaCl}_{3}$ & 1.0 & 0 \\
$\mathrm{FeCl}_{2}$ & 1.0 & 43 \\
$\mathrm{FeCl}_{3}$ & 1.0 & 25 \\
$\mathrm{MnCl}_{2}$ & & \\
$\mathrm{CuCl}_{2}$ & & \\
& &
\end{tabular}

o-phenanthroline にて $100 \%$ \%失活する. これらに各 種金属イオンを加えると，Co，Zn イオンで約 $60 \%$ 回 復する. 又, 2 洒 $\mathrm{Fe}, \mathrm{Mn}, \mathrm{Cu}$ イオンであ多少の回 復がみられる.リンタンパクと最も親和性の高いとさ れる $\mathrm{La}^{3)}$ や， $\mathrm{Ca}, \mathrm{Mg}$ では回復はみられなかった.

\section{考察}

基質小胞には，特有のプロテアーゼが存在し，てれ はコラゲナーゼ由来でないととを，抗原抗体反応にて 碓めた. 小胸内での局在については, 藤原) は deoxycholate 0.008 \%で活性最大となると述べており， 漠に存在するのではないかと述べている. Hirsch$\operatorname{man}^{52}$ らは sucrose の不連続性密度勾配遠心で基質 小胞を粕製し，プロテアーゼ活性を調べ, deoxycholate $0.02 \%$ \%゙プロテアーゼの $1.2 \%, 0.5 \%$ で約 90 \%のプロテアーゼが溶出されると述べている，本研究 では, $0.008 \%$ deoxycholate で $26 \% 0.3 \%$ で 60 \%であったが, $0.008 \%$ deoxycholate 処理後, 涷結 跨燥したあのでは，約 $90 \%$ \%の゙ロテアーゼが溶出さ 机た．乙机はプロテアーゼ活性が膛に結合していると いうよりは，小胞液に存佂しているのではないかと考 えら机る。

又，金属の種類については，藤原" $は$ は金属プロテア ゼであるてとを示したが，金属については言及してい ない，Ehrlich2) 弓は，骨端軟骨から，neutral protease を抽出し, proteoglycan を分解するととを示 し, $\mathrm{MgCl}_{2}, \mathrm{CaCl}_{2} 10 \mathrm{mM}$ でての活性が增すことを報 告しているが，乙のプロテアーゼが基質小胞由来かど
うかは不明である. 一方, Morales ${ }^{6)}$ らは軟骨細胞を 培症して, この medium から, neutral protease を拗出し，てれは， latent form で aminophenyl mercuric acetate で活性化され， o-phenanthroline で失活し, $\mathrm{CaCl}_{2}$ 存在下で, $\mathrm{Co}$ 又は $\mathrm{Zn}$ イオン で再活性化すると述べている．乙机あ基質小胞に由来 するか否かは不明であよが，金属の種類は同様であ る. 本笑鍳では $\mathrm{Ca}$ イオンの存在は無関係であった.

䛀田》は proteoglycanはハイドロキシパタイト の結晶の生長を阻害し，基質小胞によってその阻害作 用が消失するととを示している．基質小胞が小胞内に プロテアーゼを持ち，小胞内のアパタイト結晶核が生 長すると，小胞膜が破れ，プロテアーゼを放出すると 考えるならば，アパタイト結晶の生長，增殖を迎えて いたプロテオグリカンなどの非コラーゲン性タンパク が分解され，石灰化前線において有機質の脱却が起と るととを合理的に説明できる。

ま と め

1. 基質小胞には特有のプロテアーゼが存在する.

2. 基質小胞プロテアーゼは，金属プロテアーゼで あって活性の発玩には，Co 又は $\mathrm{n}$ イオンが必要で ある.

3. 精製した基質小胞プロテアーゼには，調製時に 使用したコラゲナーゼに由来するプロテアーゼの混入 はない。

\section{文献}

1) Ali, S. Y., Sajdera, S. W. and Anderson, H. C.: Isolation and characterization of calcifying matrix vesicles from epiphyseal cartilage. Proc. Nat. Acad. Sci. 67: 15131520, 1970

2 Ehrlich, M. G., Armstrong, A. L. et al.: Patterns of proteoglycan degradation by a neutral protease from human growth plate epiphyseal cartilage. J. Bone \& Joint Surg. 64-A : 1350-1354, 1982.

3）藤沢隆一，佐々木 哲：菌の高リン酸化 $\mathrm{Ca}-$ 結合蛋白一ホスホホリン一, 蛋白質核酸醭素別冊 26: 333-344, 1983.

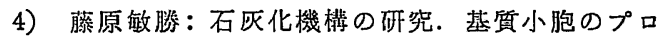
テアーゼについて，蕋基䂣誌，24：393-405, 1982.

5) Hirschman, A., Dentsch, D. et al.: Neutral peptidase activities in matrix vesicles 
from bovine fetal alveolar bone and dog sarcoma. Calcif. Tissue Int. 35: 791-797, 1983.

6) Morales, T. I. and Kuettner, K.E.: The properties of the neutral proteinase released by primary chondrocyte cultures and its action on proteoglycan aggregate. Biochi. Biophy. Acta. 705: 92-101, 1982.

7）坂田道昭：石灭化機橉の研究. 基質小胞による プロテオグリカンの分解. 崡基礎誌， 22：649660, 1980.

8) Väänänen, H. K. and Korhonen, L. K. : Matrix vesicles in chicken epiphyseal cartilage. Separation from lysosomes and the distribution of inorganic pyrophophatase activity. Calcif. Tissue Int. 28: 65-72, 1979.
質問・発言

熊本大学 石川浩一郎

Matrix Vesicles 内にCo と $\mathrm{Zn}$ を含有するメタ ロプロテアーゼがあると理解してよいでしょうか？ 採取された Matrix Vesicles 全てにこのようなメタ ロプロテアーゼがあるのでしょうか？ 石灰化に関与 するあののみにあるのでしょうか?

解 答長崎大学 山田 健治

1. プロテアーゼの基質小胞内の局在については, 膜に存在するという文献むみられるが, 高濃度の界面 活性剂（例えば deoxycholate 0.5\%や，凍結乾燥で 膜がこわれると，プロテテーゼの大部分が溶出され， 小胞内に存在するのではないかと推察される. 